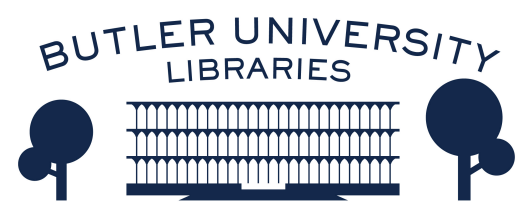

Journal of Hindu-Christian Studies

Volume 9

Article 12

January 1996

\title{
Viewpoint: Hindu-Christian "Studies": Some Confessions from the Boundaries
}

Fred W. Clothey

Follow this and additional works at: https://digitalcommons.butler.edu/jhcs

Part of the Religion Commons

\section{Recommended Citation}

Clothey, Fred W. (1996) "Viewpoint: Hindu-Christian "Studies": Some Confessions from the Boundaries," Journal of Hindu-Christian Studies: Vol. 9, Article 12.

Available at: https://doi.org/10.7825/2164-6279.1134

The Journal of Hindu-Christian Studies is a publication of the Society for Hindu-Christian Studies. The digital version is made available by Digital Commons @ Butler University. For questions about the Journal or the Society, please contact cbauman@butler.edu. For more information about Digital Commons @ Butler University, please contact digitalscholarship@butler.edu. 


\title{
VIEWPOINT
}

\section{Hindu-Christian "Studies": Some Confessions from the Boundaries}

\author{
Fred W. Clothey
}

THERE ARE TIMES I think the term Hindu-Christian "studies" or even Hindu-Christian "dialogue" is a misnomer and a fantasy. This is so for several reasons. For one thing, there is a long history in which such "study" or conversation has been a monologue, a one-way street or an interpretation by imposition. There has been too much shouting at each other from caves and not enough honesty, negotiation, and mutual respect of personhood on the boundaries between where peoples live. For another, such engagements are not and never again can be merely one on one discourses between persons with single identities. We are each increasingly persons with multiple identities, in the process of becoming different persons even as we "dialogue". None of us truly represents whatever "authentic" Christianity or Hinduism is supposed to be. Nor can any of us speak, listen, or study in isolation from the dynamics of global processes where multiple forces and multiple religions impinge on one's self-representations. Not only that: I have been increasingly pessimistic that whatever some of us as individuals may do or think, a vast majority of our coreligionists remain blissfully unaware of the need for inter-religious understanding or the desirability of rethinking fundamental metaphors in light of such conversations.

That note of pessimism voiced, I nonetheless continue to believe that those of us who are "third culture" people ${ }^{1}$ have no choice but to carry on at least an internal dialogue of study and research between the disparate cultures and religions that have shaped each of us. We do this because it is a way of expressing who we are, but we do it also aware of all those persons who are living or emerging on the boundaries Indian (and other Asian) immigrants and their children in North America and elsewhere; children of bi-religious (or even post-religious) parents; undergraduates with enlarging worlds, especially those who have studied or lived abroad; international travellers, for whom youth's assumptions have become too small to accommodate global realities. In fact, global currents, transnational mobility, and the existence of neighbours quite different from the ghettoized enclaves in which earlier generations may have grown up - all are making more of the world's people bi- or multi- cultural, bi- or multi- religious. In fact, I am more convinced now than I was when I first started to make a career of listening to the voices of Hinduism, that study and research at the boundaries between religious and other human pluralities are fundamental to the future of humankind. Granted, those of us shaped by one tradition never become part of another's and there is always a humbling limitation to what one can truly grasp or comprehend of an alternative religious orientation. But the process is paradigmatic of what education is about and what sharing a planet must entail. 
Several elements of this process of doing research across and between religious traditions - esoteric and marginalized as it may seem to many both in the academy and in religious institutions - can be consistent with the fundamental character of being human and living in community. For one thing, our research is itself collaborative and/or dialogical. No longer can I work in the splendid isolation of a library and presume to get at the "truth" of a text, a symbol, or a ritual. I am obliged to hear and see, in some cases, even smell and touch, the way such a phenomenon is lived out, interiorized, and re-interpreted by persons for whom the phenomenon has life and meaning. I cannot purport to "speak for" participants in an alternative universe, certainly not without many consultations, exchanges of questions, and help from a wide assortment of colleagues and participants. Precisely because this very process is so often flawed, fraught with "orientalism", "neo-colonialism", arrogance, and all the other foibles to which human beings are subject, we are in constant need of checking our lenses and becoming self-conscious of agendas. Yet, from at least the time of al-Biruni, scholars who have attempted to study India have found their work to be collaborative, whether or not that is acknowledged. Many of us find these collaborations to be enormously enriching to the point that we covet similar experiences for our students, colleagues and co-religionists. In fact, for a number of us, if there is a "missionary spirit" remaining in our work, it has less to do with seeking to change members of one religious persuasion to another than with wishing that all persons become thoughtful, sensitive "third culture people".

This research process also has a healing quality, for it comes in the context of a long history of wounds in Euroamerican-Indian or Hindu-Christian relationships. It is a history that has included the pejorative putdown of people like Abbe Dubois and Katherine Mayo and is embodied so succinctly in the inelegant comment made in the preface to William Ward's 1817 treatise purporting to be a study of Hinduism:

There is scarcely anything in Hindooism, when truly known, in which a learned man can delight, or of which a benevolent man can approve, and I am fully persuaded, that there will soon be but one opinion on the subject, and that this opinion will be, that the Hindoo system is ... the most PUERULE, IMPURE, AND BLOODY OF ANY SYSTEM OF IDOLATRY THAT WAS EVER ESTABLISHED ON EARTH [sic]. ${ }^{2}$

This is also a history that has included the "noble savage" paternalism implied in the title of J. N. Farquahar's The Crown of Hinduism. It has also included centuries of Christians and Hindus living in isolation from each other even while existing in the same geographical space - at best a "benign neglect", in which, nonetheless, each community is victimized by its own ignorance of the other, subject to any demagogue who wants to demonize the other. It is also a history which includes romanticized views one of the other - a romanticism in which, all too often, one sees in the other what one wants to see, only what is most like the self's most noble values-in the last analysis, a form of self-love, dishonest in that it refuses to take the other seriously on their own terms.

Collaborative research not only must constantly navigate around such shoals; it must find a way to heal implicit wounds by the seriousness with which one takes the partner. Whether or not every person with whom we engage in a research conversation is aware of that history, the researcher must be; hence each conversation becomes the opportunity for starting a new history.

Collaborative research also has a way of changing the researcher. Trying to understand another causes us to see ourselves with changing. lenses and to search for more adequate ways to self-define. Research conversations across the boundaries invite us to grope for those elements which are 
essential in affirming who each of us is and also in affirming those essential elements we share with others in the conversation. Research into an alternative religion is an invitation to set out from the theoretical and ideological harbours whence we started and to become liminal people in constant pilgrimage toward more adequate ways of answering the questions posed by a continually enlarging intellectual world. Not only are we embarrassed by the warts of our own traditions and the myopia of our disciplinary paradigms, but we struggle for more adequate paradigms and metaphors to express what we want to be and think.

This creative aspect of the research process has been recognized by various hermeneuts. Mircea Eliade spoke of a "creative humanism", Paul Ricoeur of philosophical reflection as the third stage of the hermeneutical process. Elsewhere, I have referred to three kinds of "meaning": a) "meanings" as units of intelligibility gathered from the landscape the researcher is seeking to understand; b) "meaningfulness" as the collage or tapestry one is able to construct in re-presenting that landscape; and c) "significance" as the effects of one's findings on one's home base. It is this last dimension in crosstraditional collaborative research that is, I suspect, the least commonly articulated. Our timidity at identifying publicly those areas where re-thinking is warranted is probably the result of several factors: our will to leave private the conclusions we draw inwardly; the fact that our research partners are less likely to ask us questions as to what we believe than we are to ask them; our temerity in face of the overspecialization in the academy, lest we be thought to sound like theologians who, after all, have created their own fiefdoms and relegated us to ours.

The "significance" of our collaborative research - that is, the changes it has wrought in us - deserves to become part of the public discourse and should help catalyse a rethinking of the way religion is studied and propagated in places such as North
America. To be blunt, the discipline of Religious Studies ought not to be dominated by theoretical orientations that remain Euroamerican in character. Nor should the Academy for the Study of Religion be satisfied that the paradigms for studying and organizing its work are derived largely from Protestantism. We should be insisting that seminaries no longer crank out clergy who are substantially ignorant of alternative religious orientations, particularly when people of such "world religions" are neighbours in their parishes. And we should not leave the rethinking of the essence of any religion to the "specialists"--that is to those theologians and practitioners who are steeped only in their own traditions and know only how to speak amongst each other. Shouting (even whispering) that is done in caves has a way of bouncing back from the walls and forever perpetuating itself.

As I have reflected on my own pilgrimage since I first seriously tried to understand the religious landscape of India, I am struck by the changes in self-definition and the ways in which I have come to nuance the religious metaphors that have persisted in orienting me. My experience and the ways I have rethought my own orientation are, no doubt, idiosyncratic and should not become the basis for a new religion. But my sense remains that the process that occurs in our kind of research can and should be paradigmatic for all religious persons. The fact that I have had to re-envision my cosmology and anthropology, my images of the divine, my Christology, indeed most of the fundamental metaphors of my faith, can be an invitation for any religious person living on the boundaries where people live out their faith to become "third religion" persons.

\section{Notes}

1. "Third culture people" is the term used by John Useema to describe persons who have 
been significantly shaped by more than one cultural tradition to the point that one has become transnational in orientation, fully at home in no culture, but reasonably at home in more than one culture.
2. William Ward, View of History, Literature, and Mythology of the Hindoos., 5th ed., Madras: J. Higginbotham, 1963,p. xix. 